\title{
SUPRAMOLECULAR STRUCTURE, IR SPECTROSCOPIC AND MAGNETIC STUDIES OF A NOVEL COPPER (II) COMPLEX ([Cu(phen) $\left.]_{2}\left(\mathrm{H}_{2} \mathrm{PO}_{4}\right)_{2} \mathrm{HPO}_{4}\right)_{2}\left(\mathrm{H}_{3} \mathrm{PO}_{4}\right)_{4}$
}

\author{
M. Ben Nasr ${ }^{1}$, E. Aubert ${ }^{1}$, V. Ferretti ${ }^{2}$, E. Espinosa ${ }^{1}$, P.S.P. Silva ${ }^{3}$, L.C.J. Pereira ${ }^{4}$, M.R. Silva ${ }^{3}$ \\ ${ }^{1}$ Laboratoire CRM2 (Cristallographie, Résonance Magnétique et Modélisations), Vandoeuvre lès Nancy, France \\ E-mail: mahjouba_bennasr@yahoo.fr \\ ${ }^{2}$ Department of Chemical and Pharmaceutical Sciences and Center for Structural Diffractometry, Ferrara, Italy \\ ${ }^{3}$ CFisUC, Department of Physics, University of Coimbra, Coimbra, Portugal \\ ${ }^{4}$ Solid State Group, UCQR, IST/CTN, Instituto Superior Técnico, UTL, Bobadela LRS, Portugal
}

Received February, 7, 2015

\begin{abstract}
A new $\mathrm{Cu}$ (II) complex with bidentate $o$-phenanthroline (phen) ligand, ([Cu(phen) $]_{2}\left(\mathrm{H}_{2} \mathrm{PO}_{4}\right)_{2}$. $\left.\cdot \mathrm{HPO}_{4}\right)_{2}\left(\mathrm{H}_{3} \mathrm{PO}_{4}\right)_{4}$, has been synthesized and characterized by single crystal X-ray diffraction, IR spectroscopy and magnetic data. The crystal structural analysis shows that the title compound contains two phosphate-bridged dimeric units $\left([\mathrm{Cu}(\mathrm{phen})]_{2}\left(\mathrm{H}_{2} \mathrm{PO}_{4}\right) \mathrm{HPO}_{4}\right)$, which are crystallographically independent. In these units, each copper atom is five coordinated and the geometry around the $\mathrm{Cu}(\mathrm{II})$ can be described as slightly distorted square-based pyramidal, with $\tau$ parameter varying between 0.001 and 0.04 . The crystal structure is stabilized by $\mathrm{O}-\mathrm{H} \ldots \mathrm{O}$ and $\mathrm{C}-\mathrm{H} \ldots \mathrm{O}$ hydrogen bonds between the dimeric units and the phosphoric acid molecules. In addition, the organic ligands are associated by $\pi-\pi$ stacking interactions between neighboring non-nitrogen aromatic rings. The infrared spectrum recorded at room temperature was interpreted on the basis of data published in the literature. The magnetic susceptibilities data show a weak intra-dimer ferromagnetic interaction with $J=31.8 \mathrm{~K}$.
\end{abstract}

DOI: $10.15372 / \mathrm{JSC} 20150815$

K e y w o r d s: coordination compounds, copper(II) complex, crystal structure, magnetism, IR spectroscopy, cryomagnetic.

\section{INTRODUCTION}

In recent years, synthesis and characterization of metal-organic coordination compounds have attracted much attention due to their intriguing topological frameworks and their potential use in various fields [ $1-5]$. In particular, $\mathrm{Cu}(\mathrm{II})$ complexes, whose structural flexibility allows the coordination number to vary between 4 and 6 with coordination geometries distorted to various degrees, have been extensively studied over the past few decades in view of their important applications in different research fields, such as metalloenzymes functioning and biomimetic catalysis [ 6-8], anticancer pharmacology [9 ], catalytic chemical bond activation [10 ]. Moreover, polynuclear copper(II) complexes, and in particular, dihydroxo and dialkoxo bridged $\mathrm{Cu}(\mathrm{II})$ dinuclear compounds, in which the metal centers lie close to each other, have been extensively studied both experimentally and theoretically in order to understand mutual influence of the metal centers in terms of structural, electrochemical and magnetic properties [11-14]. In these compounds the adjacent copper atoms share one or more ligands, the structural and chemical features of the bridge governing the exchange interactions among the metal centers. It is well known that in the dihydroxo and dialkoxo dinuclear $\mathrm{Cu}(\mathrm{II})$ complexes a correlation exists between the magnetic coupling constant $J$ and the values of different structural pa- 
rameters, for example the $\mathrm{Cu}-\mathrm{O}-\mathrm{Cu}$ angle, depending on which the $J$ value between $\mathrm{Cu}$ (II) ions can switch from ferromagnetic $(J>0)$ to antiferromagnetic $(J<0)$ [ 15$]$.

In order to study in detail these magnetostructural correlations, we have undertaken a systematic study on copper complexes with multidentate ligands [16,17 ]. As a part of this program, we are presenting here the preparation, X-ray crystal structure characterization, IR study and magnetic behaviour of the novel $\left([\mathrm{Cu}(\mathrm{phen})]_{2}\left(\mathrm{H}_{2} \mathrm{PO}_{4}\right)_{2} \mathrm{HPO}_{4}\right)_{2}\left(\mathrm{H}_{3} \mathrm{PO}_{4}\right)_{4}$ copper(II) complex. The ligand choice is based on diverse considerations. Ortho-phenanthroline is one of the most used chelating ligands in coordination chemistry, and more specifically, its copper complexes are subject matter of research for their role in biological systems as well as their chemical and physical properties [18]. On the other hand, transition metal phosphates constitute a large family of materials [19] exhibiting different structural motifs (3D frameworks, 2D sheets, 1D chains) [20] which are of great interest in view of potential applications in catalysis, photochemistry, electrochromism, and magnetism [21,22]. Moreover, they can provide bridging atoms to form polynuclear complexes, as shown by a search in the Cambridge Crystallographic Database (133 entries of phosphate-bridged $\mathrm{Cu}$ complexes).

\section{EXPERIMENTAL}

Chemical preparation. The title compound was prepared by adding an aqueous solution $(15 \mathrm{~mL})$ of $o$-phenanthroline $(18 \mathrm{mg}, 0.1 \mathrm{mmol})$ to an aqueous solution of $\mathrm{CuSO}_{4}(16 \mathrm{mg}, 0.1 \mathrm{mmol})$ under stirring at room temperature. An aqueous solution $(10 \mathrm{~mL})$ containing $0.5 \mathrm{mmol}$ of orthophosphoric acid was then added dropwise and the mixture was stirred for $1 \mathrm{~h}$. Crystals suitable for X-ray analysis were obtained after four days by evaporating the mixture at room temperature with a $65 \%$ yield.

Investigation techniques. The title compound has been studied by single crystal X-ray diffraction, infrared spectroscopy and cryomagnetic studies.

X-ray single crystal structural analysis. A single crystal was carefully selected under a polarizing microscope. The crystallographic data were collected on a Nonius CCD diffractometer at room temperature using graphite-monochromated $\mathrm{Mo} K_{\alpha}$ radiation $(\lambda=0.71073 \AA)$ with an $\omega$ scan followed by $\varphi$ scan to fill the sphere. All intensities were corrected for Lorentz, polarization and absorption effects [23 ]. The structure was solved by direct methods with the SIR97 program [24] and refined on $F^{2}$ using SHELX97 [25] by full matrix least-squares methods with anisotropic non-hydrogen atoms. All the hydrogen atoms were found in the difference Fourier map and refined isotropically. All other calculations were accomplished by using WingX [26]. The drawings were made with Diamond [27 ] and Mercury [28 ] programs. Crystal data are given in Table 1.

Physical measurements. The IR spectrum was recorded in the range $4000-400 \mathrm{~cm}^{-1}$ with a Perkin-Elmer FT-IR spectrophotometer 1000 using a sample dispersed in spectroscopically pure $\mathrm{KBr}$ pellet. Magnetic data were collected from a powder sample using an S700XCryogenic Ltd. superconducting quantum interference device (SQUID) magnetometer. The temperature dependence of the magnetic susceptibility curves was measured over the temperature range $5-300 \mathrm{~K}$, after zero field cooling. A small magnetic field (500 Oe) was applied during susceptibility measurements.

\section{RESULTS AND DISCUSSION}

Structure description. The X-ray structure of $\left([\mathrm{Cu}(\mathrm{phen})]_{2}\left(\mathrm{H}_{2} \mathrm{PO}_{4}\right)_{2} \mathrm{HPO}_{4}\right)_{2}\left(\mathrm{H}_{3} \mathrm{PO}_{4}\right)_{4}$ is shown in Fig. 1, and selected bond lengths and bond angles are given in Table 2. The asymmetric unit of the title inorganic-organic hybrid material contains two crystallographically independent oxygen bridged dimeric complexes $\left([\mathrm{Cu}(\text { phen })]_{2}\left(\mathrm{H}_{2} \mathrm{PO}_{4}\right)_{2} \mathrm{HPO}_{4}\right)$ and four phosphoric acid molecules. In both complexes each copper atom is five-coordinated, being linked to two nitrogen atoms of a phenanthroline ligand and three oxygen atoms from three phosphate moieties. The resulting geometry is a distorted square-based pyramide. The two crystallographically independent dimers differ in that in the first one the monohydrogenophosphate is in apical position with respect to $\mathrm{Cul}$ but equatorial with respect to $\mathrm{Cu} 2$ (Fig. 2), whereas in the second dimer both the apical positions are occupied by dihydrogenophosphate molecules. The Addison parameter expressed as $\tau=(\beta-\alpha) / 60$ with $\alpha$ and $\beta$ being the two lar- 


\begin{tabular}{|c|c|}
\hline \multicolumn{2}{|c|}{ Crystal data } \\
\hline Chemical formula & $2\left(\mathrm{C}_{24} \mathrm{H}_{21} \mathrm{Cu}_{2} \mathrm{~N}_{4} \mathrm{O}_{12} \mathrm{P}_{3}\right) \cdot 4\left(\mathrm{H}_{3} \mathrm{O}_{4} \mathrm{P}\right)$ \\
\hline$M_{\mathrm{r}}$ & 1946.85 \\
\hline Crystal system, space group & Triclinic, $P-1$ \\
\hline Temperature, $\mathrm{K}$ & 295 \\
\hline$a, b, c, \AA$ & $13.3995(1), 15.9772(1), 16.6433(2)$ \\
\hline$\alpha, \beta, \gamma$, deg. & $83.5180(4), 79.4440(5), 75.1390(4)$ \\
\hline$V, \AA^{3}$ & $3377.49(5)$ \\
\hline$Z$; Radiation type & $2 ; \operatorname{MoK}_{\alpha}$ \\
\hline$\mu, \mathrm{mm}^{-1}$ & 1.59 \\
\hline Crystal size, $\mathrm{mm}$ & $0.44 \times 0.29 \times 0.15$ \\
\hline \multicolumn{2}{|c|}{ Data collection } \\
\hline Diffractometer & Nonius Kappa CCD diffractometer \\
\hline Absorption correction & Multi-scan \\
\hline$T_{\min }, T_{\max }$ & $0.745,0.861$ \\
\hline $\begin{array}{l}\text { No. of measured, independent and } \\
\text { observed }[I>2 \sigma(I)] \text { reflections }\end{array}$ & $77551,19483,14196$ \\
\hline$R_{\text {int }}$ & 0.052 \\
\hline$(\sin \theta / \lambda)_{\max }, \AA^{-1}$ & 0.704 \\
\hline \multicolumn{2}{|c|}{ Refinement } \\
\hline$R\left[F^{2}>2 \sigma\left(F^{2}\right)\right], w R\left(F^{2}\right), S$ & $0.038,0.106,1.05$ \\
\hline No. of reflections / parameters & $19483 / 1052$ \\
\hline$\Delta \rho_{\max }, \Delta \rho_{\min }, \mathrm{e} / \AA^{3}$ & $0.55,-0.74$ \\
\hline
\end{tabular}

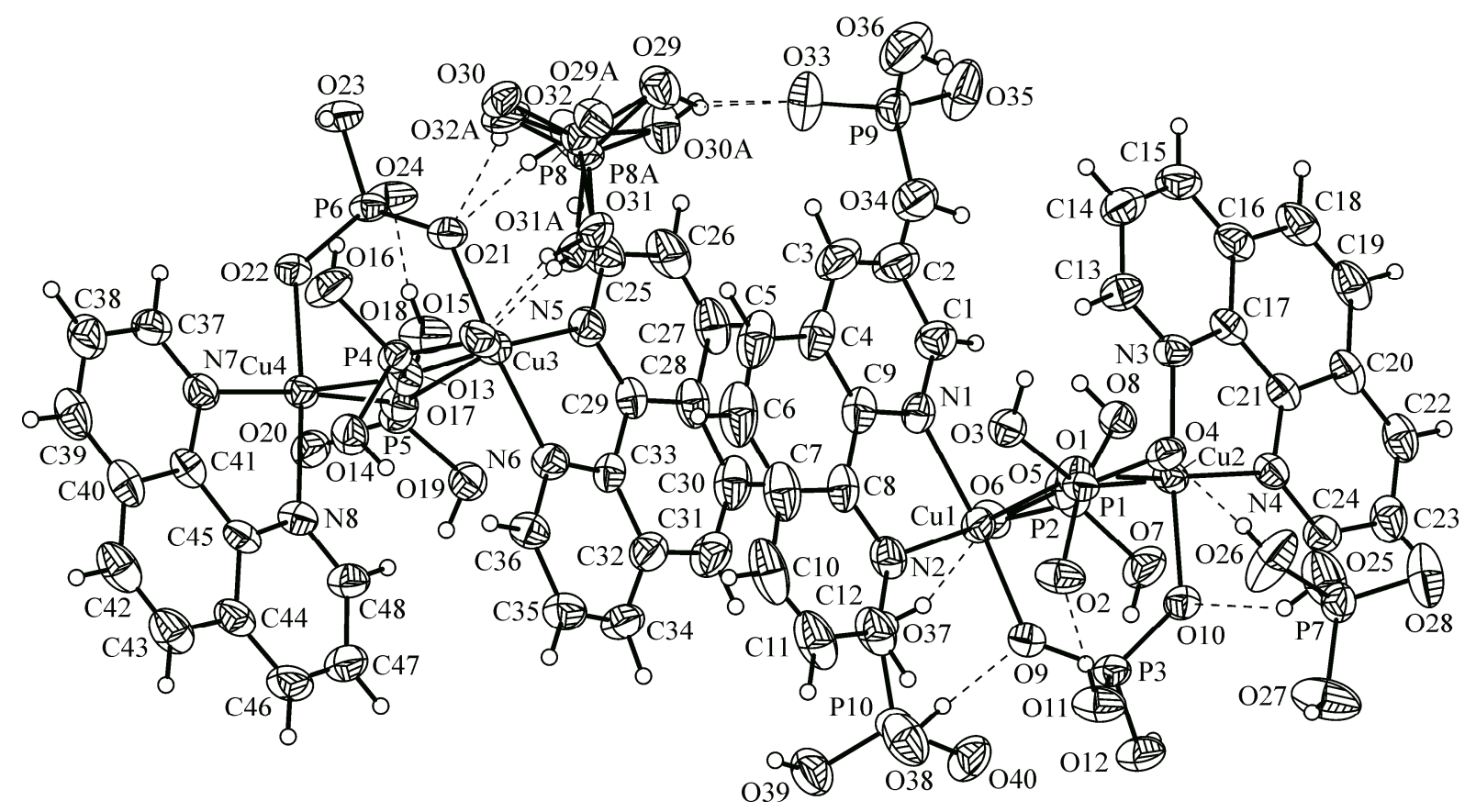

Fig. 1. Asymmetric unit of $\left([\mathrm{Cu}(\text { phen })]_{2}\left(\mathrm{H}_{2} \mathrm{PO}_{4}\right)_{2} \mathrm{HPO}_{4}\right)_{2}\left(\mathrm{H}_{3} \mathrm{PO}_{4}\right)_{4}$ with the atom numbering scheme and thermal ellipsoids at $50 \%$ probability 
T a b l e 2

Selected bond lengths $(\AA)$ and angles (deg.) of $\left([\mathrm{Cu}(\mathrm{phen})]_{2}\left(\mathrm{H}_{2} \mathrm{PO}_{4}\right)_{2} \mathrm{HPO}_{4}\right)_{2}\left(\mathrm{H}_{3} \mathrm{PO}_{4}\right)_{4}$

\begin{tabular}{|c|c|c|c|c|c|}
\hline \multicolumn{2}{|c|}{ Bond distances } & \multicolumn{4}{|c|}{ Bond angles } \\
\hline $\mathrm{Cu} 1-\mathrm{N} 1$ & $1.997(2)$ & $\mathrm{O} 9-\mathrm{Cu} 1-\mathrm{O} 5$ & $88.69(6)$ & $\mathrm{O} 13-\mathrm{Cu} 3-\mathrm{N} 6$ & $93.95(6)$ \\
\hline $\mathrm{Cu} 1-\mathrm{N} 2$ & $1.999(2)$ & $\mathrm{O} 9-\mathrm{Cu} 1-\mathrm{N} 1$ & $174.44(6)$ & $\mathrm{N} 5-\mathrm{Cu} 3-\mathrm{N} 6$ & $82.18(7)$ \\
\hline $\mathrm{Cu} 1-\mathrm{O} 9$ & $1.949(2)$ & $\mathrm{O} 5-\mathrm{Cu} 1-\mathrm{N} 1$ & $94.58(6)$ & $\mathrm{O} 21-\mathrm{Cu} 3-\mathrm{O} 17$ & $93.43(5)$ \\
\hline $\mathrm{Cu} 1-\mathrm{O} 5$ & $1.959(1)$ & $\mathrm{O} 9-\mathrm{Cu} 1-\mathrm{N} 2$ & $94.10(7)$ & $\mathrm{O} 13-\mathrm{Cu} 3-\mathrm{O} 17$ & $85.00(5)$ \\
\hline $\mathrm{Cu} 1-\mathrm{O} 1$ & $2.280(1)$ & $\mathrm{O} 5-\mathrm{Cu} 1-\mathrm{N} 2$ & $176.82(7)$ & $\mathrm{N} 5-\mathrm{Cu} 3-\mathrm{O} 17$ & $94.77(6)$ \\
\hline $\mathrm{Cu} 1 \ldots \mathrm{Cu} 2$ & $3.1005(4)$ & $\mathrm{N} 1-\mathrm{Cu} 1-\mathrm{N} 2$ & $82.51(7)$ & $\mathrm{N} 6-\mathrm{Cu} 3-\mathrm{O} 17$ & $89.03(6)$ \\
\hline $\mathrm{Cu} 2-\mathrm{N} 4$ & $1.995(2)$ & $\mathrm{O} 9-\mathrm{Cu} 1-\mathrm{O} 1$ & $94.80(6)$ & $\mathrm{O} 17-\mathrm{Cu} 4-\mathrm{O} 22$ & $90.97(6)$ \\
\hline $\mathrm{Cu} 2-\mathrm{N} 3$ & $2.004(2)$ & $\mathrm{O} 5-\mathrm{Cu} 1-\mathrm{O} 1$ & $84.96(5)$ & $\mathrm{O} 17-\mathrm{Cu} 4-\mathrm{N} 7$ & $174.83(6)$ \\
\hline $\mathrm{Cu} 2-\mathrm{O} 10$ & $1.967(1)$ & $\mathrm{N} 1-\mathrm{Cu} 1-\mathrm{O} 1$ & $89.97(6)$ & $\mathrm{O} 22-\mathrm{Cu} 4-\mathrm{N} 7$ & $94.15(6)$ \\
\hline $\mathrm{Cu} 2-\mathrm{O} 5$ & $2.336(1)$ & $\mathrm{N} 2-\mathrm{Cu} 1-\mathrm{O} 1$ & $96.31(6)$ & $\mathrm{O} 17-\mathrm{Cu} 4-\mathrm{N} 8$ & $92.47(6)$ \\
\hline $\mathrm{Cu} 2-\mathrm{O} 1$ & $1.945(1)$ & $\mathrm{O} 1-\mathrm{Cu} 2-\mathrm{O} 10$ & $90.73(6)$ & $\mathrm{O} 22-\mathrm{Cu} 4-\mathrm{N} 8$ & $174.94(7)$ \\
\hline $\mathrm{Cu} 2 \ldots \mathrm{Cu} 1$ & $3.1005(4)$ & $\mathrm{O} 1-\mathrm{Cu} 2-\mathrm{N} 4$ & $175.40(6)$ & $\mathrm{N} 7-\mathrm{Cu} 4-\mathrm{N} 8$ & $82.38(7)$ \\
\hline $\mathrm{Cu} 3-\mathrm{N} 5$ & $1.995(2)$ & $\mathrm{O} 10-\mathrm{Cu} 2-\mathrm{N} 4$ & $92.95(6)$ & $\mathrm{O} 17-\mathrm{Cu} 4-\mathrm{O} 13$ & $84.20(5)$ \\
\hline $\mathrm{Cu} 3-\mathrm{N} 6$ & $2.001(2)$ & $\mathrm{O} 1-\mathrm{Cu} 2-\mathrm{N} 3$ & $93.95(6)$ & $\mathrm{O} 22-\mathrm{Cu} 4-\mathrm{O} 13$ & $94.80(5)$ \\
\hline $\mathrm{Cu} 3-\mathrm{O} 17$ & $2.317(1)$ & $\mathrm{O} 10-\mathrm{Cu} 2-\mathrm{N} 3$ & $174.24(6)$ & $\mathrm{N} 7-\mathrm{Cu} 4-\mathrm{O} 13$ & $96.11(6)$ \\
\hline $\mathrm{Cu} 3-\mathrm{O} 21$ & $1.937(1)$ & $\mathrm{N} 4-\mathrm{Cu} 2-\mathrm{N} 3$ & $82.22(7)$ & $\mathrm{N} 8-\mathrm{Cu} 4-\mathrm{O} 13$ & $89.25(6)$ \\
\hline $\mathrm{Cu} 3-\mathrm{O} 13$ & $1.952(1)$ & $\mathrm{O} 1-\mathrm{Cu} 2-\mathrm{O} 5$ & $83.75(5)$ & & \\
\hline $\mathrm{Cu} 3 \ldots \mathrm{Cu} 4$ & $3.1092(4)$ & $\mathrm{O} 10-\mathrm{Cu} 2-\mathrm{O} 5$ & $93.81(6)$ & & \\
\hline $\mathrm{Cu} 4-\mathrm{N} 7$ & $1.983(2)$ & $\mathrm{N} 4-\mathrm{Cu} 2-\mathrm{O} 5$ & $98.75(6)$ & & \\
\hline $\mathrm{Cu} 4-\mathrm{N} 8$ & $2.013(2)$ & $\mathrm{N} 3-\mathrm{Cu} 2-\mathrm{O} 5$ & $90.03(6)$ & & \\
\hline $\mathrm{Cu} 4-\mathrm{O} 22$ & $1.953(1)$ & $\mathrm{O} 21-\mathrm{Cu} 3-\mathrm{O} 13$ & $89.52(6)$ & & \\
\hline $\mathrm{Cu} 4-\mathrm{O} 17$ & $1.946(1)$ & $\mathrm{O} 21-\mathrm{Cu} 3-\mathrm{N} 5$ & $94.35(7)$ & & \\
\hline $\mathrm{Cu} 4-\mathrm{O} 13$ & $2.351(1)$ & $\mathrm{O} 13-\mathrm{Cu} 3-\mathrm{N} 5$ & $176.13(7)$ & & \\
\hline $\mathrm{Cu} 4 \ldots \mathrm{Cu} 3$ & $3.1092(4)$ & $\mathrm{O} 21-\mathrm{Cu} 3-\mathrm{N} 6$ & $175.90(6)$ & & \\
\hline
\end{tabular}

gest angles, is zero for an ideal square pyramidal and becomes equal to one for an ideal trigonal bipyramid [29]. The calculated $\tau$ values for the title compound are $\tau(\mathrm{Cu} 1)=0.04, \tau(\mathrm{Cu} 2)=0.02, \tau(\mathrm{Cu} 3)=$ $=0.004$ and $\tau(\mathrm{Cu} 4)=0.001$, with $\alpha$ values and $\beta$ values varying in the range $174.24(6)-175.90(6)^{\circ}$ and $174.94(7)-176.13(7)^{\circ}$, respectively, indicating that the geometry has nearly a regular square based pyramidal structure. The three hydrogenophosphate anions compensate the positive charge of the two independent copper(II) cations in each dimeric unit. The cation coordination as a whole can be
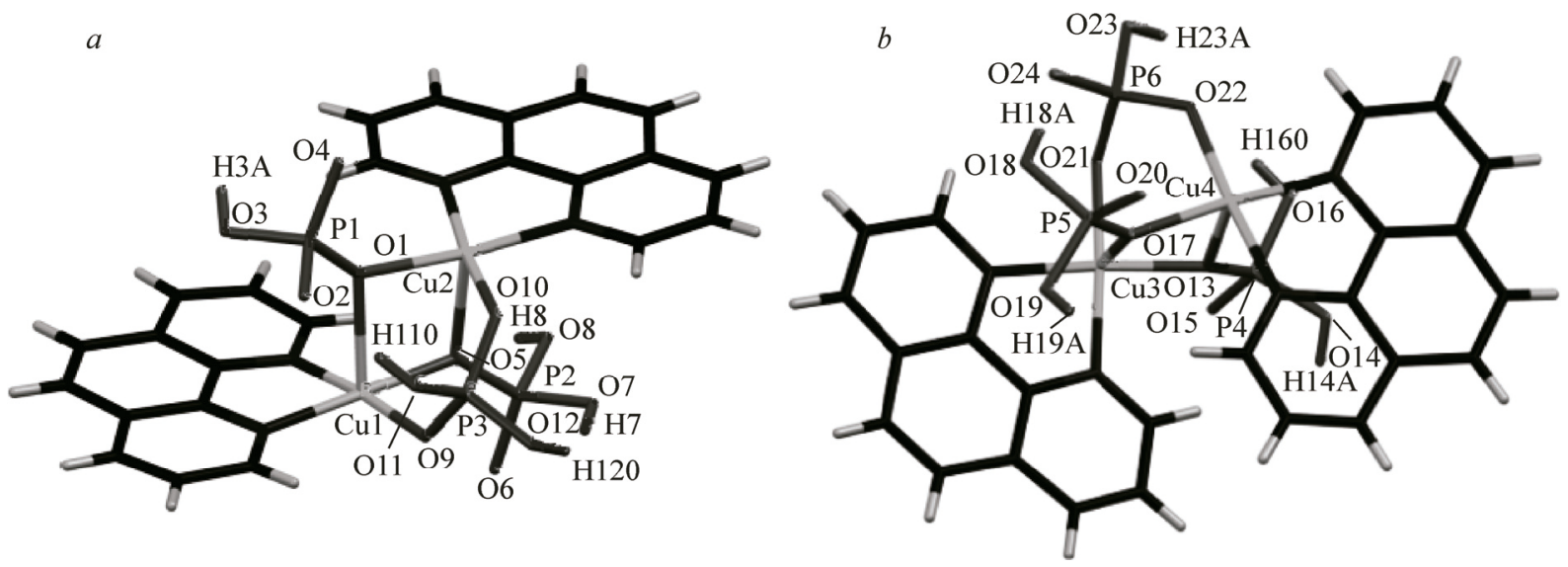

Fig. 2. Dimeric $\mathrm{Cu} 1-\mathrm{Cu} 2(a)$ and $\mathrm{Cu} 3-\mathrm{Cu} 4(b)$ units in $\left([\mathrm{Cu}(\text { phen })]_{2}\left(\mathrm{H}_{2} \mathrm{PO}_{4}\right)_{2} \mathrm{HPO}_{4}\right)_{2}\left(\mathrm{H}_{3} \mathrm{PO}_{4}\right)_{4}$ 


\begin{tabular}{l|c|c|c|c||c|c|c|c|c}
\multicolumn{8}{c}{ Hydrogen-bond geometry $(\AA$, deg. $)$ in $\left([\mathrm{Cu}(\mathrm{phen})]_{2}\left(\mathrm{H}_{2} \mathrm{PO}_{4}\right)_{2} \mathrm{HPO}_{4}\right)_{2}\left(\mathrm{H}_{3} \mathrm{PO}_{4}\right)_{4}$} \\
\hline \multicolumn{1}{c}{$D-\mathrm{H} \cdots A$} & $D-\mathrm{H}$ & $\mathrm{H} \cdots A$ & $D \cdots A$ & $D-\mathrm{H} \cdots A$ & $D-\mathrm{H} \cdots A$ & $D-\mathrm{H}$ & $\mathrm{H} \cdots A$ & $D \cdots A$ & $D-\mathrm{H} \cdots A$ \\
\hline $\mathrm{O} 3-\mathrm{H} 3 A \cdots \mathrm{O} 20^{\mathrm{i}}$ & 0.82 & 1.83 & $2.650(2)$ & 174 & $\mathrm{O} 26-\mathrm{H} 26 O \cdots \mathrm{O} 4$ & 0.82 & 1.70 & $2.497(2)$ & 162 \\
$\mathrm{O} 7-\mathrm{H} 7 \cdots \mathrm{O} 30^{\mathrm{ii}}$ & 0.82 & 1.92 & $2.615(2)$ & 141 & $\mathrm{O} 27-\mathrm{H} 27 A \cdots \mathrm{O} 2^{\mathrm{vii}}$ & 0.82 & 1.71 & $2.513(2)$ & 164 \\
$\mathrm{O} 8-\mathrm{H} 8 \cdots 6^{\mathrm{iii}}$ & 0.82 & 1.80 & $2.615(2)$ & 176 & $\mathrm{O} 29-\mathrm{H} 29 \cdots \mathrm{O} 33$ & 0.82 & 1.71 & $2.449(3)$ & 150 \\
$\mathrm{O} 11-\mathrm{H} 11 O \cdots \mathrm{O} 2$ & 0.82 & 1.75 & $2.573(2)$ & 178 & $\mathrm{O} 31-\mathrm{H} 31 A \cdots \mathrm{O} 15$ & 0.82 & 1.80 & $2.556(3)$ & 153 \\
$\mathrm{O} 12-\mathrm{H} 12 O \cdots \mathrm{O} 30^{\mathrm{ii}}$ & 0.82 & 1.68 & $2.498(2)$ & 175 & $\mathrm{O} 32-\mathrm{H} 32 \cdots \mathrm{O} 21$ & 0.82 & 1.82 & $2.633(2)$ & 170 \\
$\mathrm{O} 12-\mathrm{H} 12 O \cdots \mathrm{O} 29 A^{\mathrm{ii}}$ & 0.82 & 2.02 & $2.629(9)$ & 130 & $\mathrm{O} 30 A-\mathrm{H} 30 A \cdots \mathrm{O} 33$ & 0.82 & 1.70 & $2.333(10)$ & 132 \\
$\mathrm{C} 1-\mathrm{H} 1 \cdots \mathrm{O} 6^{\mathrm{iii}}$ & 0.93 & 2.65 & $3.460(3)$ & 145 & $\mathrm{O} 31 A-\mathrm{H} 31 B \cdots \mathrm{O} 15$ & 0.82 & 1.70 & $2.36(2)$ & 136 \\
$\mathrm{C} 13-\mathrm{H} 13 \cdots \mathrm{O} 20^{\mathrm{i}}$ & 0.93 & 2.57 & $3.308(3)$ & 136 & $\mathrm{O} 32 A-\mathrm{H} 32 A \cdots \mathrm{O} 21$ & 0.82 & 1.94 & $2.635(10)$ & 141 \\
$\mathrm{O} 14-\mathrm{H} 14 A \cdots \mathrm{O} 15^{\mathrm{iv}}$ & 0.82 & 1.82 & $2.624(2)$ & 167 & $\mathrm{O} 34-\mathrm{H} 34 O \cdots \mathrm{O} 20^{\mathrm{i}}$ & 0.82 & 1.75 & $2.527(2)$ & 157 \\
$\mathrm{O} 16-\mathrm{H} 16 O \cdots \mathrm{O} 40^{\mathrm{v}}$ & 0.82 & 1.97 & $2.668(2)$ & 143 & $\mathrm{O} 35-\mathrm{H} 35 O \cdots \mathrm{O} 24^{\mathrm{viii}}$ & 0.82 & 1.73 & $2.523(2)$ & 162 \\
$\mathrm{O} 18-\mathrm{H} 18 A \cdots \mathrm{O} 24$ & 0.82 & 1.78 & $2.592(2)$ & 172 & $\mathrm{O} 36-\mathrm{H} 36 A \cdots \mathrm{O} 22^{\mathrm{i}}$ & 0.82 & 1.93 & $2.743(2)$ & 170 \\
$\mathrm{O} 19-\mathrm{H} 19 A \cdots \mathrm{O} 4{ }^{\mathrm{vi}}$ & 0.82 & 1.76 & $2.566(2)$ & 169 & $\mathrm{O} 37-\mathrm{H} 37 O \cdots \mathrm{O} 6$ & 0.82 & 1.75 & $2.523(2)$ & 157 \\
$\mathrm{O} 23-\mathrm{H} 23 A \cdots \mathrm{O} 40^{\mathrm{v}}$ & 0.82 & 1.82 & $2.643(2)$ & 177 & $\mathrm{O} 38-\mathrm{H} 38 O \cdots \mathrm{O} 9$ & 0.82 & 1.88 & $2.695(2)$ & 174 \\
$\mathrm{O} 25-\mathrm{H} 25 A \cdots \mathrm{O} 10$ & 0.82 & 2.04 & $2.725(2)$ & 141 & $\mathrm{O} 39-\mathrm{H} 39 O \cdots \mathrm{O} 28^{\mathrm{vi}}$ & 0.82 & 1.68 & $2.445(3)$ & 155
\end{tabular}

Symmetry codes: ${ }^{\mathrm{i}} x+1, y, z ;{ }^{\mathrm{ii}} x, y+1, z ;{ }^{\mathrm{iii}}-x-1,-y,-z+1 ;{ }^{\mathrm{iv}}-x-1,-y-1,-z ;{ }^{\mathrm{v}} x, y-1, z ;{ }^{\mathrm{vi}} x-1, y, z ;{ }^{\mathrm{vii}}-x,-y$, $-z ;$ viii $-x-1,-y-1,-z+1$.

rationalized and quantified in terms of the concept of bond valence sum [30] which assumes that the total charge of a cation has to be saturated by $\Sigma s_{i}$, i.e. the summation of the separate bond valence contributions $\left(s_{i}\right)$ of each coordinated atom $i$. Quantities $s$ can be calculated by the expression $s=\exp \left[\left(r_{0}-\right.\right.$ $-r) / B$ [31] where $r$ is the actual $\mathrm{Cu}-\mathrm{O}$ or $\mathrm{Cu}-\mathrm{N}$ distance, while $r_{0}$ and $B$ are empirical parameters: $r_{0}=1.655 \AA$ and $B=0.37$ for $\mathrm{Cu}-\mathrm{O}, r_{0}=1.713 \AA$ and $B=0.37$ for $\mathrm{Cu}-\mathrm{N}$ [ 32 ]. The $s$ values obtained for the $\mathrm{Cu}^{2+}$ cations are 2.00,1.97, 2.00, and $1.98 \mathrm{for} \mathrm{Cu} 1, \mathrm{Cu} 2, \mathrm{Cu} 3$, and $\mathrm{Cu} 4$, respectively.

Selected structural parameters of the dimeric units are listed in Table 2. The $\mathrm{Cu}-\mathrm{O}$ distances involving the equatorial oxygen atoms, varying between $1.937(1) \AA$ and $1.967(1) \AA$, are much shorter than the ones involving the axial oxygen atoms, ranging from 2.280(1) $\AA$ to 2.351(1) $\AA$; this difference can be attributed to the Jahn-Teller distortion effect. Conversely, the $\mathrm{Cu}-\mathrm{N}$ distances are very similar, all being in the range 1.983(2) - 2.013(2) $\AA$, and are consistent with those normally observed in the copper(II) complexes [16,17]. The $\mathrm{Cu} 1 \ldots \mathrm{Cu} 2$ and $\mathrm{Cu} 3 \ldots \mathrm{Cu} 4$ separations are 3.1005(4) $\AA$ and 3.1092(4) $\AA$, respectively; these distances are short enough to suggest a magnetic exchange.

As for the structural features of the phosphate groups, it can be noticed that the $\mathrm{P}-\mathrm{O}$ bonds, varying between 1.471(2) $\AA$ and 1.516(1) $\AA$, are shorter than the $\mathrm{P}-\mathrm{OH}$ bonds, ranging from $1.517(2) \AA$ to $1.574(1) \AA$. This is in agreement with the data relative to the protonated oxoanions [ 33 ].

Packing. Due to the great number of $\mathrm{H}$-bond donors and acceptors, the packing pattern is mainly influenced by $\mathrm{O}-\mathrm{H} \ldots \mathrm{O}$ interactions, whose geometrical parameters are listed in Table 3 . The O... distances are generally quite short, and are typical of strong charge-assisted hydrogen bonds; actually, the longest distances correspond to bifurcated interactions. These hydrogen bonds connect the $\mathrm{H}_{3} \mathrm{PO}_{4}$ molecules with each other and with the copper complexes, leading to the formation of a complicated three dimensional network (Fig. 3) which is made more robust by a set of C-H...O weaker interactions. This uncommon richness in hydrogen bonds is a phenomenon rarely observed in simple organic or mineral compounds and could be promising as a structural model for the study of some reaction mechanisms of chemical processes in biological media.

In addition, strong intermolecular $\pi-\pi$ stacking interactions between neighboring non-nitrogen aromatic rings of 1,10-phenanthroline molecules are also observed, with a face-to-face distance of 
Fig. 3. Crystal packing of the structure of $\left([\mathrm{Cu}(\text { phen })]_{2}\left(\mathrm{H}_{2} \mathrm{PO}_{4}\right)_{2} \mathrm{HPO}_{4}\right)_{2}\left(\mathrm{H}_{3} \mathrm{PO}_{4}\right)_{4}$. The dotted lines indicate hydrogen bonds

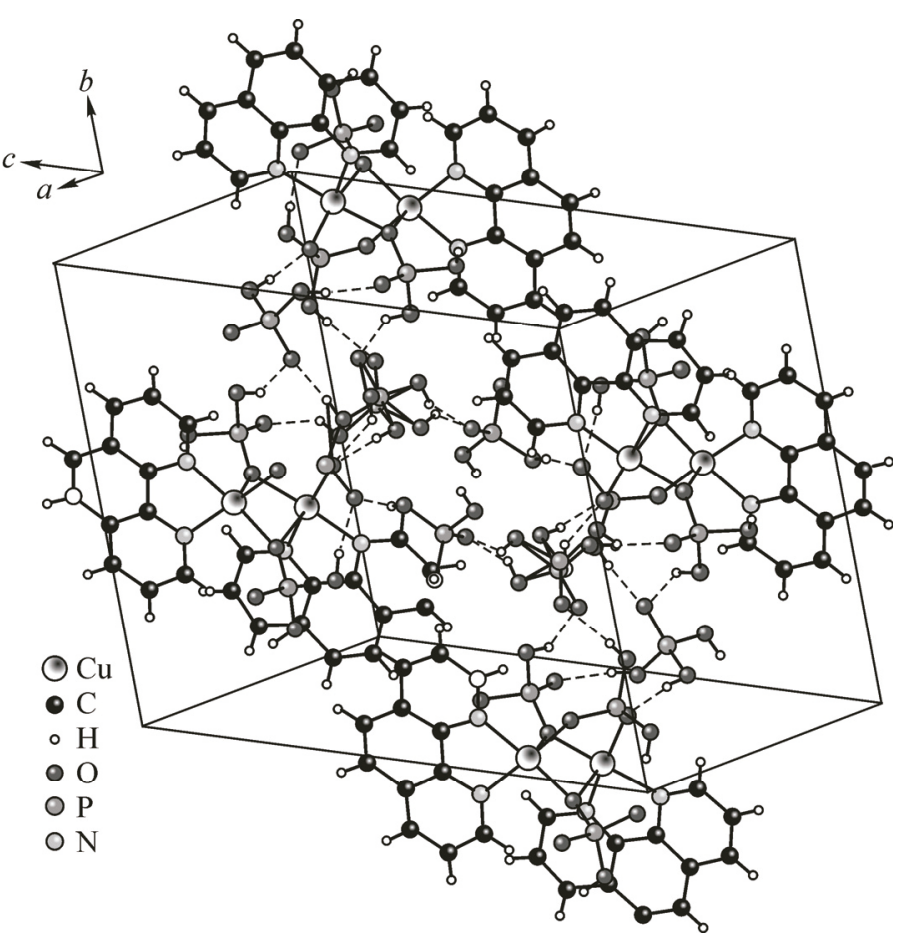

3.466(1) $\AA$, which is far less than $3.8 \AA$, i.e. the maximum value indicated for such interactions [34]. This kind of interaction has been previously observed in diaquabis(perchlorato)(1,10-phenanthroline)copper(II) [35].

IR spectroscopy. The IR spectrum of the crystalline complex $\left([\mathrm{Cu}(\text { phen })]_{2}\left(\mathrm{H}_{2} \mathrm{PO}_{4}\right)_{2} \mathrm{HPO}_{4}\right)_{2}$. $\cdot\left(\mathrm{H}_{3} \mathrm{PO}_{4}\right)$ is shown in Fig. 4. The characteristic vibrational modes of the title compound can be compared to those of similar materials [36, 37 ].

- In the high-frequency region, the very large band spreading between $3600-2200 \mathrm{~cm}^{-1}$ corresponds to the valence vibrations of $\mathrm{C}-\mathrm{H}, \mathrm{O}-\mathrm{H}$ and $\mathrm{N}-\mathrm{H}$ groups interconnected by a system of hydrogen bonds [38].

- Bands in the $1620-1100 \mathrm{~cm}^{-1}$ region correspond to the $\mathrm{O}-\mathrm{H}$ bending vibrations and to the valence vibrations of $\mathrm{C}=\mathrm{C}$ and $\mathrm{C}=\mathrm{N}$ groups [39].

- Various valence and bending vibration bands between $1200 \mathrm{~cm}^{-1}$ and $400 \mathrm{~cm}^{-1}$ are characteristic of monophosphate group [40 ]. In this case, the internal vibrations analysis of the $\mathrm{PO}_{4}$ tetrahedron has four vibrational frequencies, two stretching modes $v_{\mathrm{s}}$ and $v_{\mathrm{as}}$, respectively symmetric and asymmetric bands, and two bending modes $\delta_{\mathrm{s}}$ and $\delta_{\mathrm{as}}$. These vibrations are expected in the range 1150 $750 \mathrm{~cm}^{-1}$ and $550-350 \mathrm{~cm}^{-1}$ and $650-400 \mathrm{~cm}^{-1}$, respectively [ 41 ].

- The two bands at $854 \mathrm{~cm}^{-1}$ and $723 \mathrm{~cm}^{-1}$ are assigned to the hydrogen atoms moving out of the plane of the $o$-phenanthroline ring [ 42 ].

Magnetic susceptibility measurements. The temperature dependence of the magnetic susceptibility of the title compound was measured under an applied field of 500 Oe in the temperature range $5-300 \mathrm{~K}$, in the zero field-cooled regime.

The plot of the molar susceptibility versus $\chi T$ is shown in Fig. 5. The room temperature $\chi T$ value is close to that expected for non-interacting copper(II) ions $\left(0.375 \mathrm{~cm}^{3} \mathrm{~mol}^{-1}\right.$ with $\left.\mathrm{g}=2.0\right)$. As the temperature decreases, there is an increase of the $\chi T$ with a broad maximum around $25 \mathrm{~K}$. The overall magnetic behavior corresponds to a ferromagnetically coupled system, but the decrease at lower temperatures reveals also a weak intermolecular antiferromagnetic interaction [43] between clusters. The spin Hamiltonian takes the form

$$
\hat{H}=-J \hat{S}_{A} \hat{S}_{B}+g \beta \hat{S}_{Z} H-z J^{\prime}\left\langle S_{Z}\right\rangle \hat{S}_{Z}
$$




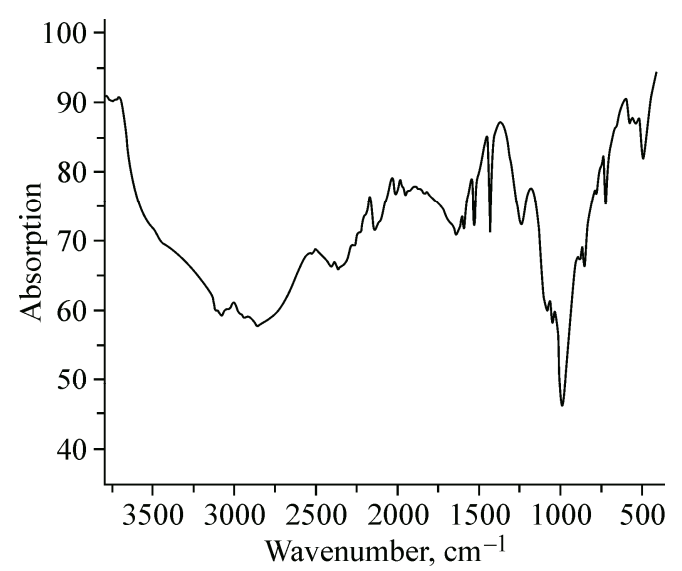

Fig. 4. IR absorption spectrum of $\left([\mathrm{Cu}(\text { phen })]_{2}\left(\mathrm{H}_{2} \mathrm{PO}_{4}\right)_{2} \mathrm{HPO}_{4}\right)_{2}\left(\mathrm{H}_{3} \mathrm{PO}_{4}\right)_{4}$

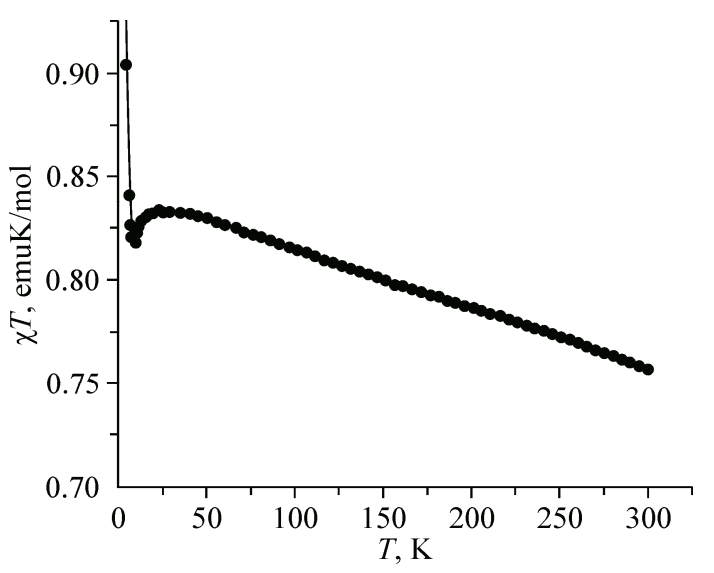

Fig. 5. Magnetic susceptibility * Temperature versus Temperature. Experimental points are shown as circles, the red straight line is a least-squares fit using the formula for susceptibility described in the text

And $\chi$ may be written down as

$$
\chi=2 N g^{2} \beta^{2}\left[k T-\frac{s z J^{\prime}}{3+\exp (-J / k T)}\right]^{-1}[3+\exp (-J / k T)]^{-1},
$$

where $\left\langle S_{Z}\right\rangle$ is the mean value of the $\hat{S}_{Z}$ component of the spin operator. $J^{\prime}$ is the interaction parameter between two nearest dimer neighbors and $z$ is the number of nearest neighbors around a given dimer in the crystal lattice. Due to their crystallographic similarity all dimers were considered magnetically equivalent. The magnetic field is assumed to be along the $z$ direction and the $g$-tensor to be isotropic. $\hat{S}_{A}$ and $\hat{S}_{B}$ are the local spin operators for the two intradimer copper ions. $J$ is the exchange parameter. In addition, a low temperature Curie contribution was used to fit the experimental data. The equation provides a good fit of experimental data in the $10-300 \mathrm{~K}$ region, yielding an exchange coupling constant of $J / k_{\mathrm{B}}=31.8 \mathrm{~K}$ and of $z J^{\prime} / k_{\mathrm{B}}$ of $-27.8 \mathrm{~K}$. The Curie term corresponds to about $0.5 \%$ of the curve and is probably due to some paramagnetic $S=1 / 2$ impurities, as is observed by the increasing of the magnetic susceptibility at very low temperatures.

\section{CONCLUSIONS}

A new $\mathrm{Cu}(\mathrm{II})$ complex with bidentate $o$-phenanthroline, $\left([\mathrm{Cu}(\mathrm{phen})]_{2}\left(\mathrm{H}_{2} \mathrm{PO}_{4}\right)_{2} \mathrm{HPO}_{4}\right)_{2}\left(\mathrm{H}_{3} \mathrm{PO}_{4}\right)_{4}$, was synthesized and characterized by various methods. On the structural level, the atomic arrangement is characterized by the presence the dimeric units $\left([\mathrm{Cu}(\mathrm{phen})]_{2}\left(\mathrm{H}_{2} \mathrm{PO}_{4}\right)_{2} \mathrm{HPO}_{4}\right.$ which are connected by $\mathrm{H}_{3} \mathrm{PO}_{4}$ molecules via a set of $\mathrm{O}-\mathrm{H} \ldots \mathrm{O}$ and $\mathrm{C}-\mathrm{H} \ldots \mathrm{O}$ hydrogen bonds, leading to the formation of a three dimensional network. Each copper atom is five-coordinated and has a slightly distorted squarebased pyramidal environment. The crystal packing is stabilized by $\pi-\pi$ stacking interactions between neighboring non-nitrogen aromatic rings. Magnetic measurements confirm the presence of ferromagnetic intra-dimer interactions. The vibrational spectra were studied by infrared spectroscopy.

Crystallographic data have been deposited with the Cambridge Crystallographic Data Centre, CCDC No 957222. These data can be obtained free of charge via http://www.ccdc.cam.ac.uk/conts/retrieving.html, or from the CCDC, 12Union Road, Cambridge, CB2 1EZ, UK: fax: (+44) 01223-336-033; e-mail: deposit@ccdc.cam.ac.

Thanks to Professor Matthias Zeller of Youngstown State University (USA) for his fruitful collaboration. 


\section{REFERENCES}

1. Yaghi O.M., O'Keeffe M., Ockwig N.W., Chae H.K., Eddaoudi M., Kim J. // Nature. - 2003. - 423. - P. 705 714.

2. Janiak C. // Dalton Trans. - 2003. - P. 2781 - 2804.

3. Mori W., Sato T., Ohmura T., Kato C.N., Takei T. // J. Solid State Chem. - 2005. - 178. - P. 2555 - 2573.

4. Dybtsev D.N., Chun H., Yoon S.H., Kim D., Kim K. // J. Am. Chem. Soc. - 2004. - 126. - P. 32 - 33.

5. Mori F., Nyui T., Ishida T., Nogami T., Choi K.-Y., Nojiri H. // J. Am. Chem. Soc. - 2006. - 128. - P. 1440 1441.

6. a) Comba P., Martin B., Muruganantham A., Straub J. // Inorg. Chem. - 2012. - 51. - P. 9214 - 9225. b) Reetz M.T. // Chem. Rec. - 2012. - 12. - P. 391 - 406. c) Mobin S.M., Sanghavi B.J., Srivastava A.K., Mathur P., Lahiri G.K. // Anal. Chem. - 2010. - 82. - P. 5983 - 5992.

7. Solomon E.I., Sundaram U.M., Machonkin T.E. // Chem. Rev. - 1996. - 96. - P. 2563 - 2605.

8. Zippel F., Ahlers F., Werner R., Haase W., Noltine H.F., Krebs B. // Inorg. Chem. - 1996. - 35. - P. 3409.

9. Marzano C., Pellei M., Tisato F., Santini C. // Med. Chem. - 2009. - 9. - P. $185-211$.

10. Singh A., Spiccia L. // Coord. Chem. Rev. - 2013. - 257. - P. 2607 - 2622.

11. Sharma R.P., Saini A., Monga D., Venugopalan P., Jezierska J., Ozarowski A., Ferretti V. // New J. Chem. - 2014. - 38. - P. 437 - 447.

12. Karlin K.D., Kaderli S., Zuberbühler A.D. // Acc. Chem. Res. - 1997. - 30. - P. 139 - 147.

13. Vigato P.A., Tamburini S., Fenton D.E. // Coord. Chem. Rev. - 1990. - 106. - P. 25 - 170.

14. Mahapatra S., Halfen J., Wilkinson A.E.C., Pan G., Cramer C.J., Que L., Jun L.Q., Tolman W.B. // J. Am. Chem. Soc. - 1995. - 117. - P. 8865.

15. Sharma R.P., Saini A., Venugopalan P., Ferretti V., Spizzo F., Angeli C., Calzado C.J. // New J. Chem. - 2014. - 38. - P. $574-583$.

16. Kaabi K., Zeller M., Ferretti V., Silva P.S.P., Ben Nasr C. // Inorg. Chim. Acta. - 2012. - 388. - P. 52 - 59.

17. Kaabi K., Zeller M., Ben Nasr C. // Elixir Chem. Phys. - 2012. - 43. - P. 6877 - 6882.

18. a) Martínez Medina J.J., Islas M.S., López Tévez L.L., Ferrer E.G., Okulik N.B. // J. Mol. Struct. - 2014. - 1058. - P. 298 - 307. b) Duskova K., Gude L., Arias-Pérez M.-S. // Tetrahedron. - 2014. - 70. - P. 1071 1076.

19. Cheetham A.K., Ferey G., Loiseau T. // Angew. Chem., Int. Ed. Engl. - 1999. - 38. - P. 3269 - 3292.

20. Rishi S.K., Kariuki B.M., Checker N.J., Godber J., Wright A.J. // Chem. Comm. - 2006. - P. 747 - 749.

21. Katsoulis D.E. // Chem. Rev. - 1998. - 98. - P. $327-357$.

22. Pope M.T. Heteropoly and Isopoly Oxometales. - Berlin: Springer-Verlag, 1983.

23. Blessing R.H. // Acta Crystallogr. - 1999. - A51. - P. 33 - 38.

24. Altomare A., Burla M.C., Kamalli M., Cascarano G., Giacovazz C., Guagliardi A., Moliterni A.G., Polidori G., Spagna R. // J. Appl. Crystallogr. - 1999. - 32. - P. 115 - 119.

25. Sheldrick G.M. SHELXS-97. A Program for Automatic Solution of Crystal Structure. - Germany: University of Göttingen, 1997.

26. Farrugia L.J. // J. Appl. Crystallogr. - 1999. - 32. - P. 837 - 838.

27. Brandenburg K. Diamond Version 2.0. Crystal Impact GbR. - Bonn, Germany, 1998.

28. Macrae C.F., Bruno I.J., Chisholm J.A., Edgington P.R., McCabe P., Pidcock E., Rodriguez-Monge L., Taylor R., van de Streek J., Wood P.A. // J. Appl. Crystallogr. - 2008. - 41. - P. 466 - 470.

29. Addison A.W., Nageswara R.T., Reedijk J., Rijn J., Verschoor G.J. // Chem. Soc., Dalton Trans. - 1984. - P. $1349-1356$.

30. Brown I.D. // Chem. Soc. Rev. - 1978. - 7. - P. $359-376$.

31. Brown I.D., Altermatt D. // Acta Crystallogr. - 1985. - B41. - P. $244-247$.

32. Shields G.P., Raithby P.R., Allen F.H., Motherwell W.D.S. // Acta Crystallogr. - 2000. - B56. - P. 455 465.

33. Ferraris G., Ivaldi G. // Acta Crystallogr. - 1998. - B40. - P. 1 - 6.

34. Janiak J. // J. Chem. Soc., Dalton Trans. - 2000. - P. 3885 - 3896.

35. Kaabi K., El Glaoui M., Zeller M., Ben Nasr C. // Acta Crystallogr. - 2010. - E66. - P. m1145 - m1 146.

36. Kaabi K., Ben Nasr C., Lefebvre F. // Mater. Res. Bull. - 2004. - 39. - P. $205-215$.

37. Mrad M.L., Ben Nasr C., Rzaigui M., Lefebvre F. // Phosphorus, Sulfur Silicon Relat. Elem. - 2006. - 181. - P. $1625-1635$.

38. Smirani W., Ben Nasr C., Rzaigui M. // Mater. Res. Bull. - 2004. - 39. - P. 1103 - 1111.

39. Oueslati A., Kefi R., Ben Nasr C., Lefebvre F. // J. Mol. Struct. - 2007. - 871. - P. 49 - 58.

40. Kaabi K., Rayes A., Ben Nasr C., Rzaigui M., Lefebvre F. // Mater. Res. Bull. - 2003. - 38. - P. 741 - 747.

41. Nakamoto K. Infrared and Raman spectra of Inorganic and Coordination Compounds. - New York: Wiley, Intersciences, 1984.

42. Schilt A.A., Taylor R.C. // J. Inorg. Nucl. Chem. - 1959. - 9. - P. $211-221$.

43. Kahn O. Molecular Magnetism. - New York: Wiley, Intersciences, 1993. 